\title{
Use of Augmented Reality in Chemistry Education
}

\author{
Pavlo P. Nechypurenko ${ }^{1[0000-0001-5397-6523]}$, Tetiana V. Starova ${ }^{1[0000-0001-7995-3506]}$, \\ Tetiana V. Selivanova ${ }^{10000-0003-2635-1055]}$, Anna O. Tomilina ${ }^{1[0000-0002-8529-4882]}$ \\ and Aleksandr D. Uchitel ${ }^{20000-0002-9969-0149]}$ \\ ${ }^{1}$ Kryvyi Rih State Pedagogical University, 54, Gagarina Ave., Kryvyi Rih, 50086, Ukraine \\ ${ }^{2}$ Kryvyi Rih Metallurgical Institute of the National Metallurgical Academy of Ukraine, \\ 5, Stephana Tilhy St., Kryvyi Rih, 50006, Ukraine \\ acinonyxleo@gmail.com, simaneneko@ukr.net, \\ \{vitro090, anna.tomilina.anna\}@gmail.com, o.d.uchitelei.ua
}

\begin{abstract}
The purpose of this article is to analyze the current trends in the use of the augmented reality in the chemistry education and to identify the promising areas for the introduction of AR-technologies to support the chemistry education in Ukrainian educational institutions. The article is aimed at solving such problems as: the generalization and analysis of the scientific researches results on the use of the augmented reality in the chemistry education, the characteristics of the modern AR-tools in the chemistry education and the forecasting of some possible areas of the development and improvement of the Ukrainian tools of the augmented reality in the chemistry education. The object of research is the augmented reality, and the subject is the use of the augmented reality in the chemistry learning. As a result of the study, it has been found that AR-technologies are actively used in the chemistry education and their effectiveness has been proven, but there are still no Ukrainian software products in this field. Frequently ARtechnologies of the chemistry education are used for $3 \mathrm{D}$ visualization of the structure of atoms, molecules, crystalline lattices. The study has made it possible to conclude that there is a significant demand for the chemistry education with the augmented reality that is available via the mobile devices, and accordingly the need to develop the appropriate tools to support the chemistry education at schools and universities. The most promising thing is the development of methodological recommendations for the implementation of laboratory works, textbooks, popular scientific literature on chemistry with the use of the augmented reality technologies and the creation of the simulators for working with the chemical equipment and utensils using the augmented reality.
\end{abstract}

Keywords: augmented reality, chemistry education, technology of the augmented reality (AR-technology), 3D model.

\section{$1 \quad$ Introduction}

The reformation of school education happening in accordance with the conception "New Ukrainian School" includes the changes into the pupils' competence set, among 
which some of them could be distinguished: the innovation, the information-communication and digital competences, the competences in the Natural Sciences, the techniques and technologies, the lifelong learning and etc.

The main method of providing the effectiveness of the educational reform implies the end-to-end using of information-communication technologies in the educational process and the management of the establishments and the system of education. The system application of ICT in the education has to expand essentially the teachers' possibilities, to organize the interaction between the teacher and students, to form students' technological competences that are important to our century.

The reformation of school education provides for the increase of the project, command and group pupils' activity in the educational process. According to this fact the variants of the educational organization will be varied especially by using mobile workplaces that are easily transformed for the group activity. The planning and design of the educational space will be aimed at the child's development and his/her motivation to the learning by means of ICT, the multimedia devices, the laboratory renovation for the studying natural-mathematic subjects [10].

Children today are getting used to data availability, possibility to obtain data whenever and anywhere they may need it. They are getting accustomed to the virtual reality as well. Therefore, so called SMART-education which implies the use of smartphones, tablets, interactive blackboards and other devices with internet access is becoming more popular $[25 ; 26]$.

The integration of an educational process with the use of mobile devices and computers, real objects with virtual ones, acquisition of necessary data about the objects which are being studied with their three-dimensional visualization is made possible due to augmented reality [18].

According to the definition of Ronald T. Azuma, Augmented Reality (AR) is a type of the virtual environment (or virtual reality) which complements an objective reality but does not change it entirely. Augmented reality allows a user to see a real world with virtual objects being either imposed or joined with the real world [4]. Augmented reality can be potentially applied to all the senses of a person, that is, audition, olfaction, somatosensation, however, the most frequent supplement is vision.

The major features of the augmented reality are a combination of both real and virtual objects in the real environment, a real-time environmental operational practice, interactivity, equalization of the peculiarities of real and virtual objects [3].

Chemistry is considered to be a complicated science due to the use of notions which cannot become the objects of direct comprehension and as a result students have to create images, virtual objects exactly in their imagination. Not all students are able to create such objects or to create them in an appropriate way for the reality that is why means of teaching intended for intensifying visibility are of always concern in the process of chemistry teaching $[20 ; 21 ; 22]$. Augmented reality is considered to be one of such modern tools. 


\section{Exposition of Basic Material of Research}

Despite a fifty year long history of the development of the conception of augmented reality, in chemistry teaching practice technologies of augmented reality (ARtechnologies) have been actively used since the beginning of the $2000 \mathrm{~s}$. It is due both to the development of the software for creating and simulating the systems of augmented reality and the increase in the availability of mobile devices with the necessary functional specifications which has made it possible for students to use ARtechnologies not only in special laboratories (as a rule, in computer labs), but in chemistry laboratories and other special chemical facilities.

A considerable amount of experience has been gained not only in terms of methods of creating and using augmented reality tools in the process of chemistry teaching but in terms of the assessment of its didactic significance, influence on the learning process, advantages and disadvantages while studying certain disciplines of chemistry as well.

In particular, Zeynep Tachgin together with the co-authors have pointed out that technologies of augmented reality are the most essential ones for studying non-perceptible notions (atom, molecule, chemical bonds etc.) and emphasized the necessity of involving experts on the scientific and methodological issues in the process of choosing the content and designers in the process of improving the quality of graphic design [30]. It has been noted that the quality of 3D-models and graphic interface of tools of chemistry teaching which use augmented reality has a positive influence on the users' level of interest in the discipline and a corresponding increase of acquiring knowledge [9].

$\mathrm{Su} \mathrm{Cai}$ together with the co-authors [5] have determined the development of students' spatial thinking, their ability to imagine and interpret three-dimensional structures of molecules and crystals to be the leading direction of the use of AR-technologies in the process of chemistry teaching. The results of their study have proved a positive influence of the use of technologies of augmented reality on the level of interest in chemistry acquiring, the level of progress in the sphere of 'Composition and structure of substances', the level of spatial awareness concerning the composition of substances. However, these researches have pointed out that the visualization of certain issues of studying has negatively impacted on the comprehension of textual information and has diverted their attention from the instructions and explanations presented in a written form.

The use of augmented reality tools created on the base of freely accessible software in the learning process has made it possible for a group of Spanish researches to determine the increase in the level of interest in chemistry acquisition, the development of comprehension about the crystal structure of substances and the improvement of students' skills to interpret two- and three-dimensional schemes. The participants of the study have noted the possibility to handle three-dimensional models and to perceive them from sides and different angles to be the main advantages of technologies of augmented reality [23]. Similar results have been achieved in the study held among students in the process of organic chemistry learning [27].

Dragos Daniel Iordache together with the co-authors [11] have detected a favourable impact of the technologies of augmented reality on the effectiveness of knowledge acquisition of the notions of chemical bonds, the law of periodicity, a periodic table of 
chemical elements mainly due to the possibility to interact with the atom and molecule models simultaneously receiving necessary explanations.

The use of 3D-models of molecules for intensifying the effectiveness of organic chemistry [13] and biochemistry [16] teaching is of particular importance. As it provides the opportunity for students to examine the structure of molecules thoroughly and to do it from different angles and it contributes to improving the understanding of bonds between the structures of molecules and properties of the substances.

A growing interest in chemistry learning due to chemical reaction modelling via technologies of augmented reality that is by visualization tools of chemical experiments (particularly dangerous and conducted with difficulties) has been considered worth noting by a group of researches [32;34].

Also a considerable potential of technologies of augmented reality not only in chemistry teaching but in the sphere of chemical studies such as: modelling, intermolecular interaction, mechanisms of chemical reactions, molecular design etc. has been detected $[14 ; 19]$.

Therefore, the effectiveness of the use of AR-technologies as tools of intensifying the process of chemistry teaching is undeniable on condition of their methodologically appropriate use.

The generalization of the existing experience of the use of technologies of augmented reality in the process of chemistry teaching makes it possible to determine some key directions of their use:

1. visualization and granularity of the structure of objects and simulation of their interaction which are inaccessible for the direct observation;

2. additional data provision about the objects in written, visual or audio-visual forms;

3. simulation of work with different equipment in order to master and to develop skills of dealing with them.

The comparison of particular characteristics of certain supporting tools of chemistry teaching via the use of technologies of augmented reality is represented in Table 1.

Table 1. Supporting tools of chemistry teaching via the use of augmented reality

\begin{tabular}{|c|c|}
\hline Name of tools & Description of features \\
\hline $\begin{array}{l}\text { Arloon Chemistry } \\
\text { [1] }\end{array}$ & $\begin{array}{l}\text { 3D-modelling of the process of molecular or crystal creation from } \\
\text { individual atoms }\end{array}$ \\
\hline $\begin{array}{l}\text { Augmented } \\
\text { Chemical } \\
\text { Reactions [14] }\end{array}$ & $\begin{array}{l}\text { 3D-visualization of molecules, their spatial dynamics and } \\
\text { interaction, possibility to form molecules from individual } \\
\text { fragments }\end{array}$ \\
\hline Augment [15] & ization of molecules and crystal lattices \\
\hline $\begin{array}{l}\text { Study Marvel- } \\
\text { Chemistry AR }\end{array}$ & $\begin{array}{l}\text { 3D-illustrations and models in special printed educat } \\
\text { textbooks and publications on chemistry }\end{array}$ \\
\hline $\begin{array}{l}\text { AR VR Molecules } \\
\text { Editor Free [33] }\end{array}$ & $\begin{array}{l}\text { nic and inorganic compounds } \\
\text { ick, scale models etc.) }\end{array}$ \\
\hline
\end{tabular}




\begin{tabular}{|l|l|}
\hline \multicolumn{1}{|c|}{ Name of tools } & \multicolumn{1}{|c|}{ Description of features } \\
\hline [12] & $\begin{array}{l}\text { Visualization of the atom structure of all chemical elements with } \\
\text { the possibility to look through additional data } \\
\text { Chemistry [7] }\end{array}$ \\
\hline $\begin{array}{l}\text { HTMoL - AR } \\
\text { plugin [28] }\end{array}$ & $\begin{array}{l}\text { 3D-modelling of molecular structures with the possibility to use the } \\
\text { computational characteristics of molecules and semiautomatic } \\
\text { animation for reactions through linear interpolation of atom } \\
\text { coordinated between gradual computational stages of reactions }\end{array}$ \\
\hline Elements4D [6] & $\begin{array}{l}\text { Availability of additional information and images of appearance of } \\
\text { substances, possibility to model chemical reactions between them }\end{array}$ \\
\hline EVToolbox [8] & $\begin{array}{l}\text { Russian-language resource of modelling interactions between } \\
\text { atoms with the creation of molecules and structure of molecules } \\
\text { and their interaction with each other }\end{array}$ \\
\hline AR Learning [31] & $\begin{array}{l}\text { Modelling of certain chemical reactions and physical and chemical } \\
\text { processes }\end{array}$ \\
\hline $\begin{array}{l}\text { MEL Chemistry } \\
\text { [17] }\end{array}$ & $\begin{array}{l}\text { 3D-modelling and molecular animation, structure of crystal } \\
\text { lattices, detection of substances according to the special markers }\end{array}$ \\
\hline
\end{tabular}

In most cases augmented reality software used as supporting tools of chemistry teaching operates in accordance with the classical pattern: selection of an image and its identification as a marker $\rightarrow$ search of a model corresponding to the marker $\rightarrow$ an imposition of the model (as a rule, it is a 3D one) on the image of the marker and its demonstration on the screen of the device.

The following things can serve as markers:

1. artificial markers (images on the plane something similar to QR-codes or other images);

2. chemical symbols;

3. real objects.

Typically only two first types of markets are used in augmented reality tools to support chemistry teaching. It is justified by the simplicity of the creation of connection between a marker and a model and a high operational stability of this system. Whereas real objects are almost of no use and do not serve as markers.

The publication of AR-books - printed books (popular scientific literature, textbooks and teaching manuals) with the elements of AR-technologies is becoming some kind of modern trend of nowadays in the use of AR-technologies. The Hungarian authors [24] have described their experience of creation AR-textbook on chemistry for secondary schools (certain sections of the syllabus for the ninth grade). The authors have conducted an experiment and the results of which have led to the conclusion about a higher level of effectiveness of the use of AR-textbooks in comparison with ordinary ones.

The group of authors from the Republic of Turkey has suggested a set of images [2] to be used for the introduction of structures of atom elements, molecular structure of water, salt, carbon (II) oxide. Suggested set of cards has been represented as a science publication on chemistry. 


\section{Conclusion and Estimation of Perspective ways of Development}

Augmented reality tools in chemistry teaching are used on the introductory stage of new material and knowledge acquiring and on the stages of learned content retention and systematization, stages of preparations for laboratory tests, for conducting tests or modelling a process of their implementation (in case they are dangerous or their implementation is impossible due to other reasons), independent study, knowledge check and self-check.

The following should be attributed to the main advantages of the use of technologies of augmented reality in chemistry teaching:

- granularity and 3D-modelling of objects which are inaccessible for the direct observation (taking into account expensive or rare equipment) which used to be represented as spatial images and schemes;

- mobility and availability to users;

- simplicity of use and comprehension;

- the possibility to use both in formal and informal education;

- modernity which highlighted interest is explained by;

- considerable potential allowing to create different supporting tools of chemistry teaching.

Most modern AR-technologies of supporting chemistry teaching are aimed solely at the visualization of molecular and crystal structures, atom and molecular structures.

There is no known Ukrainian-language product among wide spread tools of augmented reality in chemistry teaching. Although, the use of most AR-technologies to chemistry teaching is user friendly there is still a necessity to create Ukrainian ARtechnologies of high-quality for supporting chemistry teaching.

Taking into account an urgent necessity to reform and modernize the system of education in Ukraine, we consider the creation and implementation of technologies of augmented reality of chemistry teaching in the learning process on different levels: basic and specialized secondary education, different levels of technical and vocational education and higher education to be one of the key tasks of our further work.

The creation of AR-technologies of chemistry teaching, Ukrainian analogues of already known foreign tools, is being planned. It is planned to create tools which will apply possibilities of augmented reality in chemistry teaching which are of little use now. Training manuals, text books, methodical recommendations on doing chemistry laboratory works, popular scientific literature and handbooks with the support of augmented reality, 3D-modelling of molecules etc. should be named among AR-tools of the first group. As for the second group it is planned to create AR-tools of chemistry teaching which provide the opportunity for getting additional information about glassware and equipment, capturing the essence and mechanism of their functioning, modelling their application, creating tools to conduct chemical experiments from different sections of chemistry virtually, using equations of chemical reactions or chemical formulas of substances etc. as markers. 


\section{References}

1. Arloon: Arloon Chemistry. https://play.google.com/store/apps/details?id=com.Arloon.Chemistry.AR (2017). Accessed 31 Dec 2017

2. Artırılmış Gerçeklik Element Kartları: AR Bilim Kartları (Augmented Reality Element Cards: AR Science Cards). Ders Zamanı Yayınları (2017)

3. Azuma, R., Baillot, Y., Behringer, R., Feiner, S., Julier, S., MacIntyre, B.: Recent Advances in Augmented Reality. IEEE Computer Graphics and Applications. 21(6), 34-47 (2001)

4. Azuma, R.T.: A Survey of Augmented Reality. Presence: Teleoperators and Virtual Environments. 6(4), 355-385 (1997). doi:10.1162/pres.1997.6.4.355

5. Cai, S., Wang, X., Chiang, F.-K.: A case study of Augmented Reality simulation system application in a chemistry course. Computers in Human Behavior. 37, 31-40 (2014). doi:https://doi.org/10.1016/j.chb.2014.04.018

6. DAQRI: Elements 4D by DAQRI. https://play.google.com/store/apps/details?id=com.daqri.elements4dbydaqri\&utm_source=www.apk4fun.com (2013). Accessed 31 Dec 2017

7. Dáskalos: Dáskalos Chemistry: interactive science teacher for augmented reality. https://prefrontalcortex.de/labs/daskalos/periodicSystem.pdf (2015). Accessed 25 Dec 2017

8. EligoVision: EV Toolbox. http://evtoolbox.ru/ (2018). Accessed 30 Jan 2018

9. Fjeld, M., Fredriksson, J., Ejdestig, M., Duca, F., Botschi, K., Voegtli, B., Juchli, P.: Tangible user interface for chemistry education: comparative evaluation and re-design. In: CHI'07: Proceedings of the SIGCHI conference on Human factors in computing systems, San Jose, April 28 - May 3 2007, pp. 805-808 (2007). doi:10.1145/1240624.1240745

10. Hryshchenko, M. (ed.): Nova ukrainska shkola: kontseptualni zasady reformuvannia serednoi shkoly (New Ukrainian School: Conceptual Principles for Reforming the Secondary School). Ministerstvo osvity i nauky Ukrayiny. https://mon.gov.ua/storage/app/media/zagalna\%20serednya/nova-ukrainska-shkola-compressed.pdf(2016). Accessed 28 June 2017

11. Iordache, D.D., Pribeanu, C., Balog, A.: Influence of specific AR capabilities on the learning effectiveness and efficiency. Studies in Informatics and Control. 21(3), 233-240 (2012). doi:10.24846/v21i3y201201

12. Larngear Technology: Atomic Structure AR Learning Gear. http://larngeartech.com/products/atomic-structure-ar-learning-gear/ (2012). Accessed 31 Dec 2017

13. Maier, P., Klinker, G.: Augmented chemical reactions: An augmented reality tool to support chemistry teaching. In: Proceedings 2013 2nd Experiment@ International Conference (exp.at'13), University of Coimbra, Coimbra, 18-20 Sept. 2013, pp. 164-165 (2013). doi:10.1109/ExpAt.2013.6703055

14. Maier, P., Tönnis, M., Klinker, G.: Dynamics in Tangible Chemical Reactions. World Academy of Science, Engineering and Technology International Journal of Chemical and Molecular Engineering. 3(9), 442-448 (2009)

15. McCormack, P.: Augmented Reality. Innovative Education.org. http://www.innovativeeducation.org/blog/augmented-reality (2014). Accessed 29 Jan 2018

16. Medina, E., Chen, Y.-C., Weghorst, S.: Understanding Biochemistry with Augmented reality. In: Montgomerie, C., Seale, J. (eds.) Proceedings of ED-MEDIA 2007 - World Conference on Educational Multimedia, Hypermedia \& Telecommunications, Vancouver, 25 Jun 2007, pp. 4235-4239. Association for the Advancement of Computing in Education (AACE), Waynesville (2007) 
17. MEL Science: MEL Chemistry. https://melscience.com/en/app/ (2018). Accessed 19 Jan 2018

18. Modlo, E.O., Echkalo, Yu.V., Semerikov, S.O., Tkachuk, V.V.: Vykorystannia tekhnolohii dopovnenoi realnosti u mobilno oriientovanomu seredovyshchi navchannia VNZ (Using technology of augmented reality in a mobile-based learning environment of the higher educational institution). Naukovi zapysky, Seriia: Problemy metodyky fizyko-matematychnoi i tekhnolohichnoi osvity. 11(1), 93-100 (2017)

19. Musio, B., Mariani, F., Śliwiński, E.P., Kabeshov, M.A., Odajima, H., Ley, S.V.: Combination of Enabling Technologies to Improve and Describe the Stereoselectivity of WolffStaudinger Cascade Reaction. Synthesis. 48(20), 3515-3526 (2016)

20. Nechypurenko, P.P., Semerikov, S.O., Selivanova, T.V, Shenayeva, T.O.: Information and communication tools for pupils' research competence formation at chemistry profile learning. Information Technologies and Learning Tools. 56(6), 10-29 (2016)

21. Nechypurenko, P.P., Semerikov, S.O., Tomilina, L.I.: Teoretyko-metodychni zasady vykorystannia informatsiino-komunikatsiinykh tekhnolohii yak zasobu formuvannia doslidnytskykh kompetentnostei starshoklasnykiv u profilnomu navchanni khimii (Theoretical and methodical foundations of using ICT as a tools of forming the senior pupils' research competencies in the chemistry profile learning). Publishing Department of the SIHE "Kryvyi Rih National University", Kryvyi Rih (2018)

22. Nechypurenko, P.P., Semerikov, S.O.: VlabEmbed - the New Plugin Moodle for the Chemistry Education. In: Ermolayev, V., Bassiliades, N., Fill, H.-G., Yakovyna, V., Mayr, H.C., Kharchenko, V., Peschanenko, V., Shyshkina, M., Nikitchenko, M., Spivakovsky, A. (eds.) ICT in Education, Research and Industrial Applications. Integration, Harmonization and Knowledge Transfer 2017, 13th International Conference on ICT in Education, Research and Industrial Applications. Integration, Harmonization and Knowledge Transfer (ICTERI, 2017), Kyiv, Ukraine, 15-18 May 2017. CEUR Workshop Proceedings (CEUR-WS.org), vol. 1844, pp. 319-326 (2017)

23. Núñez, M., Quirós, R., Núñez, I., Carda, J.B., Camahort, E.: Collaborative Augmented Reality for Inorganic Chemistry Education. In: EE'08 Proceedings of the 5th WSEAS/IASME international conference on Engineering education, Heraklion, 22-24 July 2008, pp. 271277. World Scientific and Engineering Academy and Society (WSEAS), Stevens Point (2008)

24. Pasaréti, O., Hajdú, H., Matuszka, T., Jámbori, A., Molnár, I., Turcsányi-Szabó M.: Augmented Reality in education. In: INFODIDACT Informatika Szakmódszertani Konferencia. http://people.inf.elte.hu/tomintt/infodidact_2011.pdf(2011). Accessed 17 Jan 2018

25. Semerikov, S., Teplytskyi, I., Shokaliuk, S.: Mobilne navchannia: istoriia, teoriia, metodyka (Mobile learning: history, theory, methodic). Informatyka ta informatsiini tekhnolohii v navchalnykh zakladakh. 6, 72-82 (2008)

26. Semerikov, S., Teplytskyi, I., Shokaliuk, S.: Mobilne navchannia: istoriia, teoriia, metodyka (Mobile learning: history, theory, methodic). Informatyka ta informatsiini tekhnolohii v navchalnykh zakladakh. 1, 96-104 (2009)

27. Singhal, S., Bagga, S., Goyal, P., Saxena V.: Augmented Chemistry: Interactive Education System. International Journal of Computer Applications. 49(15), 1-5 (2012). doi:10.5120/7700-1041

28. Sliwinski, E.P., Kabeshov, M.A., Ley, S.V.: HTMoL - AR plugin: A web-based interactive 3D molecular viewer with Augmented Reality \& Holographic Display. GitHub. https://github.com/es605/HTMoLAR (2018). Accessed 21 Jan 2018

29. StudyMarvel AR: StudyMarvel - Chemistry AR. https://play.google.com/store/apps/details?id=com.StudyMarvelAR.ImmersiveChemistryAR (2016). Accessed 31 Dec 2017 
30. Taçgin, Z., Uluçay, N., Özüağ, E.: Designing and Developing an Augmented Reality Application: A Sample of Chemistry Education. Journal of the Turkish Chemical Society, Section C: Chemical Education. 1(1), 147-164 (2016)

31. Tintisha Technologies: AR Learning. http://www.arlearning.co.uk/\#about (2018). Accessed 21 Jan 2018

32. Tuli, N., Mantri, A.: Augmented Reality as Teaching Aid: Making Chemistry Interactive. Journal of Engineering Education Transformations. Special Issue, Jan, 187-191 (2015). doi:http://dx.doi.org/10.16920/jeet\%2F2015\%2Fv0i0\%2F59624

33. Virtual Space LLC: AR VR Molecules Editor Free. https://play.google.com/store/apps/details?id=com.vspaces.molb free (2017). Accessed 25 Dec 2017

34. Wojciechowski, R., Cellary, W.: Evaluation of learners' attitude toward learning in ARIES augmented reality environments. Computers \& Education. 68, 570-585 (2013). doi:10.1016/j.compedu.2013.02.014 